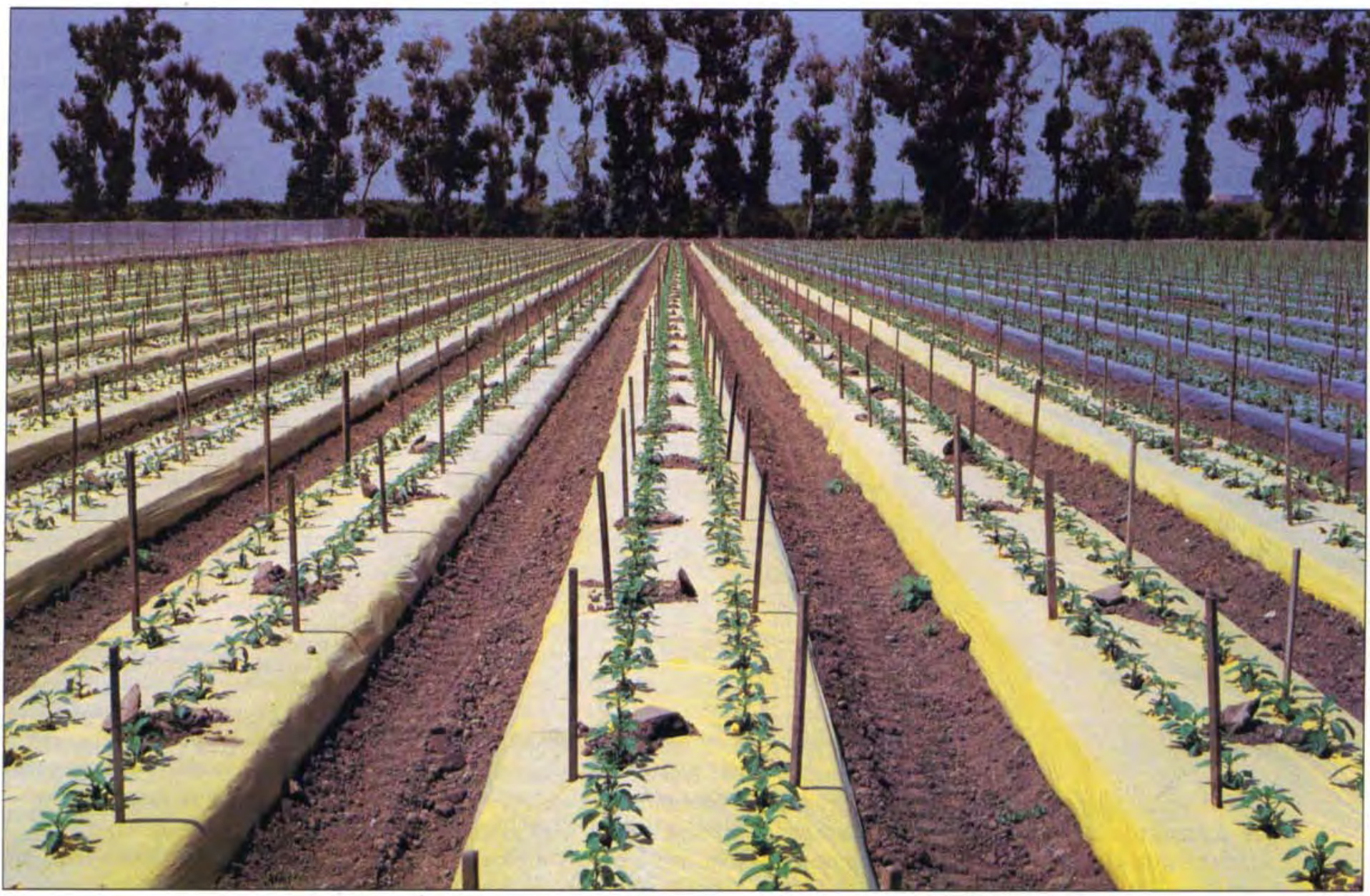

Environmental concerns are focusing attention on nitrogen management of vegetable crops.

\title{
On-farm nitrogen tests improve fertilizer efficiency, protect groundwater
}

\author{
Timothy K. Hartz $\square$ Richard F. Smith $\square$ Kurt F. Schulbach $\square$ Michelle LeStrange
}

\author{
Nitrogen fertility of high-value \\ vegetable crops must be carefully \\ managed to prevent contamina- \\ tlon of groundwater whlle meet/ng \\ agronomic goals. New on-farm \\ techniques of monitoring nitrogen \\ are simple, qulck and fairly rell- \\ able. Routlne fleld monitoring in \\ conjunction with perlodic testing \\ by conventional laboratory analy- \\ sis can save time and money.
}

Nitrogen fertilization of high-value vegetable crops has historically been managed with the goal of maximum productivity rather than maximum fertilizer efficiency. There has been little incentive to monitor nitrogen use carefully, given the relatively low cost of nitrogen fertilizer in relation to other production inputs. However, increasing focus on the negative environmental consequences of overfertilization, particularly regarding nitrate pollution of surface water and groundwater, is providing an impetus for more careful nitrogen management.

Laboratory analysis of soil and plant tissue has been, and remains, the standard method of determining crop and soil nitrogen status. Unfortunately, the significant costs and time lag between sampling and result have 


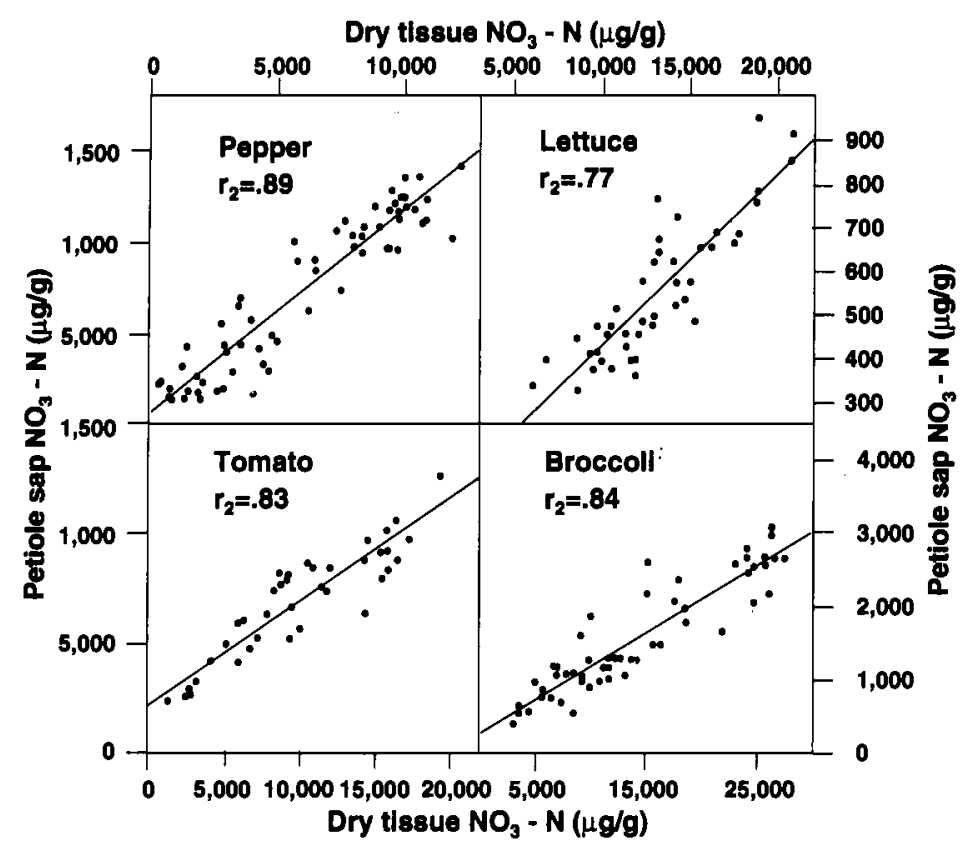

Fig. 1. Relationship between $\mathrm{NO}_{3}-\mathrm{N}$ concentration of petiole sap and dry petiole tissue for selected crops.

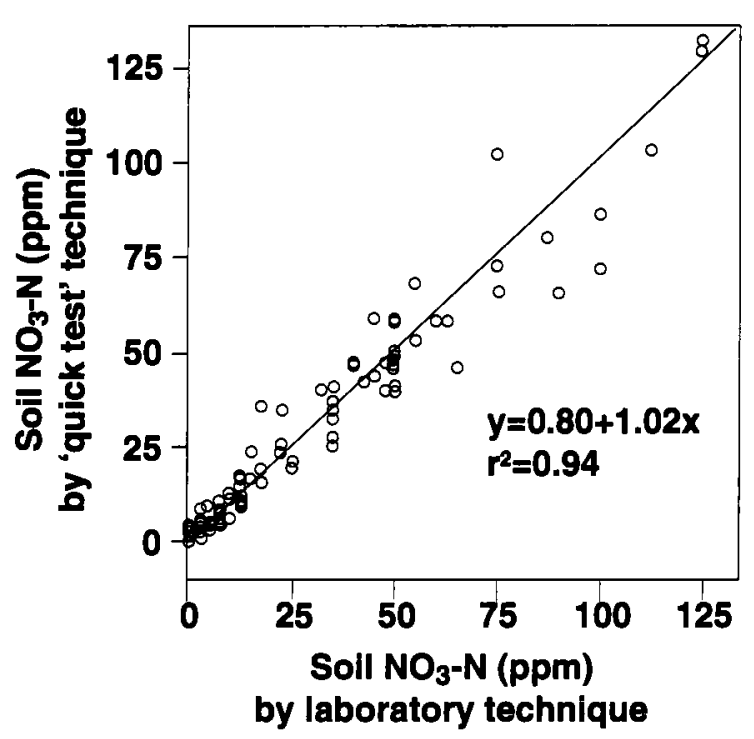

Fig. 2. Soll $\mathrm{NO}_{3}-\mathrm{N}$ concentration as measured by the quick test procedure and standard laboratory analysis. limited the number of commercial growers whose fertilization decisions are based on laboratory analysis of either soil or plant tissue.

On-farm quick test techniques for nitrogen analysis have been sought for many years. Chemical test kits are now available; however, their cost and somewhat laborious test procedures have limited routine use of such kits. We have worked on developing nitrogen quick tests for both soil and plant tissue. The tissue test involves the measurement of the nitrate content of fresh petiole sap by a portable, battery-operated, nitrate-selective electrode. The soil test procedure involves the extraction of nitrate through a simple volumetric dilution method, with nitrate concentration measured by selective electrode or colorometric test papers.

\section{Sap analysis}

Plant sampling and analysis were conducted from 1991 to 1993 in research plots and commercial fields throughout California. Tissue sampled varied by crop: whole petioles of mature, recently expanded leaves in broccoli, pepper, tomato and watermelon; midrib of the youngest wrapper leaf in lettuce; and the basal portion of petiole (below the first node) of fully expanded celery leaves. Thirty to 60 petioles or midribs comprised each sample. Sampling usually took place between 8 a.m. and 2 p.m. Samples were immediately placed in plastic bags on ice in a cooler, where they were held until analysis, usually within 3 hours.

We divided the samples, ovendrying half the tissue at $140^{\circ} \mathrm{F}$. The dried tissue was ground, extracted and analyzed for nitrate-nitrogen $\left(\mathrm{NO}_{3}-\mathrm{N}\right)$ concentration by conventional laboratory technique (acetic acid extraction method).

The remaining tissue was pressed in a handheld apparatus to extract petiole sap. The sap was analyzed for $\mathrm{NO}_{3}-\mathrm{N}$ concentration by the nitrateselective electrode meter manufactured by the Horiba Corporation of Japan. The meter was calibrated at least twice daily using potassium nitrate standard solutions. Sap was analyzed directly without dilution or filtration. All analysis was performed in a laboratory at room temperature.

The impact of site, cultivar and crop growth stage on the relationship between fresh sap and dry petiole $\mathrm{NO}_{3}$ $\mathrm{N}$ concentration was determined for broccoli, lettuce, pepper and tomato.
Tissue samples were collected from multiple field sites, representing different cultivars at differing stages of crop maturity from early vegetative growth to harvest. Additionally, multiple cultivars of watermelon at one field site were sampled across growth stages.

Nitrate concentration of petiole sap, as measured by selective electrode, was highly correlated with conventional laboratory analysis of dry petiole tissue for all crops tested. The relationship was linear across a wide range of nitrate concentrations (fig. 1). Cultivar and site did not significantly influence the relationship in any crop tested. For all crops tested in which recently matured tissue was always sampled, growth stage was not a significant factor. The only crop in which growth stage influenced the relationship was sweet corn, where the tissue sampled (basal $10 \mathrm{~cm}$ of main stalk) was aging with successive sampling dates; the use of separate regression equations for presilking and postsilking samples gave reasonably good correlations. Table 1 summarizes the numerical relationship of $\mathrm{NO}_{3}-\mathrm{N}$ concentrations of fresh petiole sap and dry tissue. The slope of the regression line differed widely among crops, emphasizing the need to determine the 
specific relationship of petiole sap to dry tissue $\mathrm{NO}_{3}-\mathrm{N}$ for each crop of interest. For example, the relationship for tomato would be inaccurate for pepper.

To determine whether sap extracted under varying pressures differed in nitrate concentration, we sequentially pressed broccoli and tomato petiole samples three times at increasing pressure, with collection of approximately equal amounts of sap at each pressing. This procedure was replicated 8 times for tomato and 10 times for broccoli. By the last pressing, all sap easily extracted by hand had been removed. The pressure with which petiole sap was extracted had no significant effect on the $\mathrm{NO}_{3}-\mathrm{N}$ concentration for either crop.

We examined the effect of length of tissue storage on sap nitrate concentration in broccoli petioles. Tissue was collected, placed in plastic bags and refrigerated at $40^{\circ} \mathrm{F}$. Analysis of $\mathrm{NO}_{3}-\mathrm{N}$ in petiole sap was performed on four samples of 10 petioles each at $0,2,6$, 12 and 24 hours after tissue collection. Broccoli petioles showed a trend toward decreasing sap nitrate concentration with increasing time between sampling and analysis; however, sap $\mathrm{NO}_{3}-\mathrm{N}$ concentration after 6 hours of storage was still $97 \%$ of the concentration immediately after sampling, indicating that short-term storage under appropriate conditions (refrigerated in plastic bags) will not substantively alter sap $\mathrm{NO}_{3}-\mathrm{N}$ concentration.

The nitrate-selective electrode functioned well in the analysis of petiole sap across a range of vegetable crops. This technique for sap analysis has the significant advantage of simplicity over colorometric methods, which can require dilution, filtration and use of reagents. Because the relationship between petiole sap and dry tissue $\mathrm{NO}_{3}-\mathrm{N}$ concentration is generally consistent across varieties and growth stages, it is relatively easy to calculate $\mathrm{NO}_{3}-\mathrm{N}$ sufficiency values for sap by applying the regression equations in table 1 to established dry tissue standards.

There are several important factors to consider regarding sap analysis. Plant water stress may significantly alter the $\mathrm{NO}_{3}-\mathrm{N}$ concentration of petiole sap. In this study, all samples were drawn from well-watered fields; sampling was also generally completed by early afternoon to miss the most stressful portion of the day. Sap $\mathrm{NO}_{3}-\mathrm{N}$ measurements could be corrected for differences in relative water content of the petioles, but this would require a drying oven and an analytical scale, complicating the procedure significantly. Production environments with radically different temperature and light regimes (i.e., summer vs. winter production) may show different petiole sap to dry tissue relationships. All data presented here represent warm weather conditions conducive to rapid growth.

The nitrate-selective electrode is sensitive to temperature fluctuations. Efficient on-farm use would entail collection of samples from multiple fields to be processed and analyzed in a central, indoor location and would require proper storage and handling. Finally, testing a representative sample is crucial for accuracy. At least 10 to 20 petioles collected throughout the field should be pressed and their sap blended before analysis.

The portable, battery-operated, nitrate-selective electrode showed promise as an on-farm tool for routinely monitoring crop nitrogen status. The most appropriate use of this instrument would be for routine field monitoring in conjunction with periodic testing by conventional laboratory techniques.

\section{Soil analysis}

The soil test procedure we evaluated relied on volumetric measurement of both soil and extracting solu-

TABLE 1. Relationship of $\mathrm{NO}_{3}-\mathrm{N}$ concentration of petiole sap and dry petiole tissue for selected crops

\begin{tabular}{lll}
\hline \hline Crop & Regression equation & $\mathrm{r}^{2}$ \\
\hline $\begin{array}{l}\text { Broccoli } \\
\text { Celery }\end{array}$ & $y=272+0.092 x$ & .84 \\
Corn & $y=21+0.038 x$ & .88 \\
$\begin{array}{l}\text { pre-silking } \\
\text { post-silking }\end{array}$ & $y=197+0.055 x$ & .65 \\
Lettuce & $y=104+0.150 x$ & .72 \\
Pepper & $y=36+0.040 x$ & .77 \\
Tomato & $y=83+0.110 x$ & .89 \\
Watermelon & $y=231+0.047 x$ & .83 \\
\hline
\end{tabular}

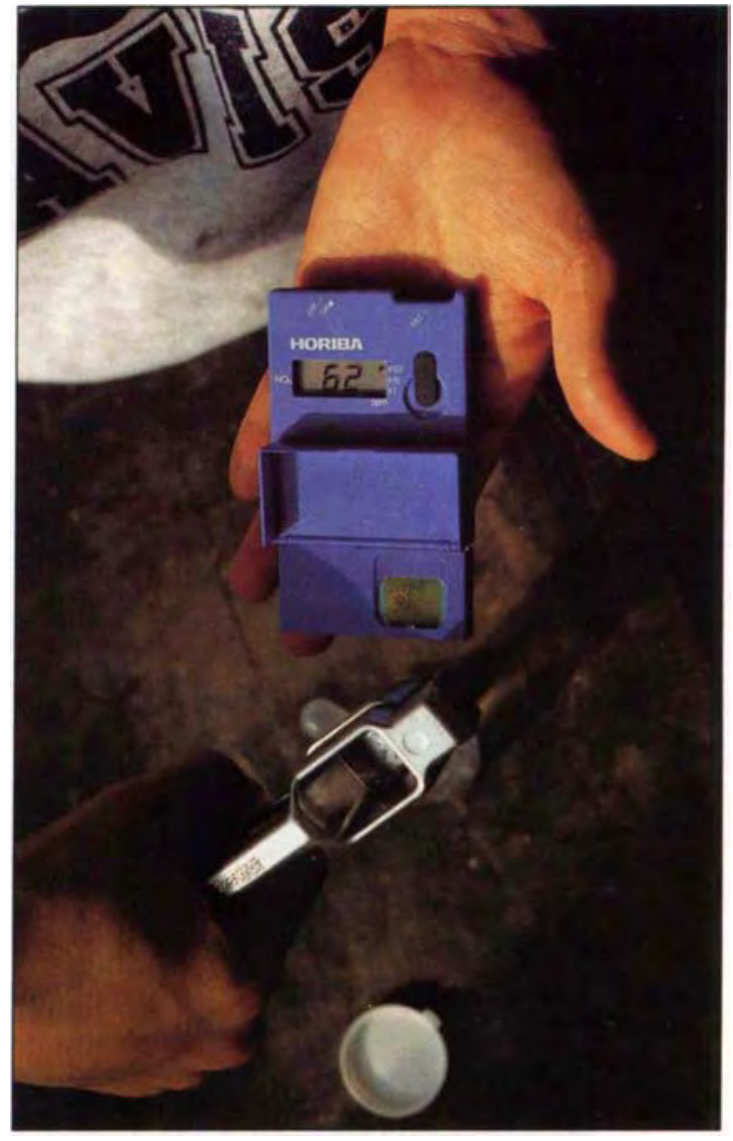

Petiole sap was analyzed for $\mathrm{NO}_{3}-\mathrm{N}$ concentration by the nitrate-selective electrode meter manufactured by the Horiba Corporation of Japan.

tion. The intent was to eliminate the need to dry, grind or weigh soil. Nearly 100 soil samples, representing 25 different fields, were assayed. Soil texture ranged from coarse sand to clay; soil moisture at sampling varied from 6 to $30 \%$ on a dry soil weight basis. Field-moist soil cores 8 to 12 inches deep were collected and blended by hand to form a uniform sample. One subsample was extracted in 2 normal $\mathrm{KCl}$ and analyzed for $\mathrm{NO}_{3}-\mathrm{N}$ concentration by conventional laboratory technique. Another subsample was assayed by the quick test procedure.

In the quick test procedure, 30 milliliters of $0.025 \mathrm{M}$ aluminum sulfate $\left(\mathrm{Al}_{2}\left[\mathrm{SO}_{4}\right]_{3}\right)$ extractant was measured into a volumetrically marked plastic centrifuge tube. Soil was then added until the level of extractant had risen to the 40-milliliter mark, a volumetric addition of 10 milliliters of soil. The centrifuge tube was capped, vigorously shaken to disperse soil aggregates and allowed to settle until a clear supernatant, liquid above the precipi- 

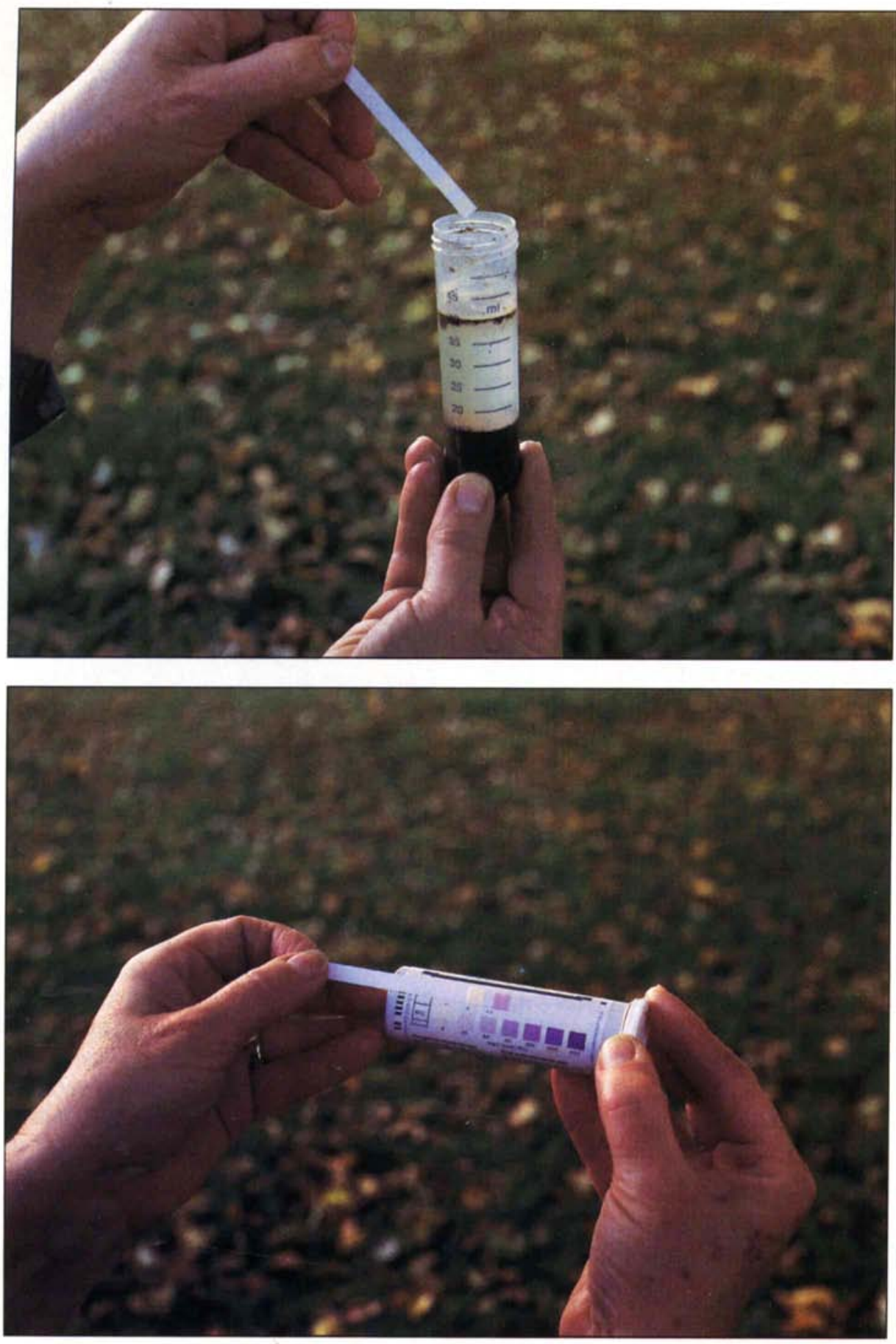

tate, formed (which usually took 1 to 3 hours).

Nitrate concentration in the supernatant was determined by the nitrateselective electrode or by nitrate-sensitive colorometric test papers (made by EM Science, Gibbstown, New Jersey). Where the nitrate-selective electrode was used, the extractant was spiked with 10 ppm $\mathrm{NO}_{3}-\mathrm{N}$ (as potassium nitrate), the lower limit of nitrate detec-
Above left, quick test soil extract ready for measurement.

Below left, reading colorometric test paper.

sample, the quick test procedure (using colorometric test papers) was highly correlated $\left(\mathrm{r}^{2}=0.95\right)$ with the standard laboratory technique. Analysis of quick test samples by nitrateselective electrode or nitrate-selective colorometric paper was equally well correlated to laboratory analysis.

However, the intent of the quick test was to be able to estimate $\mathrm{NO}_{3}-\mathrm{N}$ concentration of soil without having to accurately weigh or dry soil. When the $\mathrm{NO}_{3}-\mathrm{N}$ concentration of all samples was calculated on the basis of the mean soil dry weight and moisture percentage, the quick test procedure was still highly correlated with the standard laboratory technique (fig. 2). When only soils from 0 to $40 \mathrm{ppm}$ $\mathrm{NO}_{3}-\mathrm{N}$ (the range of primary interest in fertility decision making) were considered, the two techniques were still in close agreement $\left(r^{2}=0.87\right)$.

The test strips are calibrated in ppm $\mathrm{NO}_{3}$. Using this simple equation:

$$
\begin{aligned}
& \frac{\text { test strip }}{2} \\
& \text { ppm } \mathrm{NO}_{3}
\end{aligned}=\begin{aligned}
& \mathrm{ppm} \mathrm{NO}_{3}-\mathrm{N} \\
& \text { in dry soil }
\end{aligned}
$$

to convert from test strip reading to soil $\mathrm{NO}_{3}-\mathrm{N}$ content gave a good numerical match between quick test values and laboratory analysis (regression equation: $y=-0.8+1.02 x$.

In summary, we find petiole sap analysis by nitrate-selective electrode and the soil nitrate quick test procedure to be valuable on-farm techniques for monitoring crop and soil nitrogen status. The most appropriate use of these techniques would be for routine field monitoring in conjunction with periodic testing by conventional laboratory techniques. tained were corrected for the $\mathrm{NO}_{3}-\mathrm{N}$ content of the extracting solution.

Across the soils measured, the volumetric addition of 10 milliliters of field-moist soil contained a mean of $17.4 \pm 1.7$ grams (standard error) dry weight of soil with a mean moisture content of $17 \pm 6 \%$. When $\mathrm{NO}_{3}-\mathrm{N}$ concentration was calculated on the basis of actual weight of dry soil in each Vegetable Crops Department, UC Davis; Richard F. Smith, Kurt F. Schulbach and Michelle LeStrange are Cooperative Extension Farm Advisors in San Benito, Monterey and Tulare Counties, respectively.
Timothy K. Hartz is Extension Specialist, 